\title{
EVALUACIÓN SEROLÓGICA DE LOS VIRUS RESPIRATORIO SINCITIAL Y PARAINFLUENZA 3 EN BOVINOS DE CUSCO
}

\author{
Serological Evaluation of Respiratory Syncytial (RS) and Parainfluenza 3 \\ (PI3) Viruses in Cattle from Cusco
}

\author{
Galim Solís G. ${ }^{1}$, Hermelinda Rivera G. ${ }^{1,2}$, Néstor Falcón P. ${ }^{3}$
}

\section{Resumen}

El objetivo del presente estudio fue determinar la seroprevalencia de los virus Respiratorio Sincitial (RS) y Parainfluenza 3 (PI3) en bovinos de tres comunidades de la provincia de Espinar, Cusco. Se colectaron 406 muestras de sangre de bovinos mayores de 6 meses de edad, de ambos sexos, para la detección de anticuerpos contra los virus RC y PI3 mediante la prueba de neutralización viral. El 85.0 y $87.4 \%$ de los animales presentaron anticuerpos contra los virus RS y PI3, respectivamente, siendo mayor la frecuencia de animales positivos en los grupos etarios de 13 a 24 y $>24$ meses de edad. Los títulos de anticuerpos contra ambos virus tuvieron un rango de $2 \mathrm{a}>256$, donde títulos de anticuerpos de 16 a 64 contra el virus RS y PI3 se detectaron en el 61.4 y $58.3 \%$ de los animales. El $76.4 \%$ de los animales tuvieron anticuerpos contra ambos virus. Los resultados indican que los virus RS y PI3 están ampliamente distribuidos en los bovinos de las tres comunidades.

Palabras clave : Virus Respiratorio Sincitial, Parainfluenza 3, bovino, anticuerpos, neutralización viral

\section{Abstract}

The objective of the present study was to determine the seroprevalence of respiratory syncytial (RS) and parainfluenza 3 (PI3) viruses in cattle from three communities of the province of Espinar, Cusco, Perú. Blood samples were collected from 406 cattle older than 6 months of age of both sexes for the detection of antibodies against the RC and PI3 viruses by viral neutralization test. The 85.0 and 87.4 of animals presented antibodies against the RS and PI3 viruses, respectively, where animals with 13-24 and >24 months old were the most affected age groups. Antibody titres against both viruses had a range of 2 to $>256$, where antibody titres of 16-64 against RS and PI3 viruses were detected in

\footnotetext{
${ }^{1}$ Laboratorio de Microbiología y Parasitología Veterinaria, Facultad de Medicina Veterinaria, Universidad Nacional Mayor de San Marcos, Lima

2 E-mail: hriverag2005@yahoo.es

${ }^{3}$ Facultad de Veterinaria y Zootecnia, Universidad Peruana Cayetano Heredia, Lima
} 
61.4 and $58.3 \%$ of the animals. Antibodies against both viruses were detected in $76.4 \%$ of the animals. The results revealed that the RS and PI 3 viruses are widely distributed in the cattle population of the three communities.

Key words: Respiratory syncytial virus, Parainfluenza 3 virus, cattle, antibodies, viral neutralization

\section{INTRODUCCIÓN}

La industria lechera del país está concentrada principalmente en tres cuencas: Arequipa, Cajamarca y Lima (MINAG, 1996), pero el desarrollo de la ganadería lechera se encuentra expandiéndose a zonas como Trujillo en La Libertad y el Mantaro en Junín. Sin embargo, en el futuro mediato es posible que incremente su desarrollo en los valles interandinos del Cusco y Puno, donde hay posibilidades de recursos forrajeros que abaratarían el costo de producción.

Ccañipía es una pequeña cuenca en la provincia de Espinar, Cusco, ubicada a más de $4000 \mathrm{msnm}$, donde se cría ganado bovino producto del cruce de criollo con Brown Swiss; con una población aproximada de 1900 cabezas dedicadas a la producción de leche en manos de más de 100 pequeños criadores pertenecientes a las comunidades de Huisa Ccollana, Anta Ccollana y Huarca, en el distrito de Yauri. Los animales son criados en forma extensiva con pastos naturales y cultivados. Las enfermedades respiratorias, el mal de altura y los abortos son las enfermedades más frecuentes observadas en los bovinos de la zona, representando el $31 \%$ del total de enfermedades identificadas en la microcuenca (Alagón, 2007).

Estudios serológicos realizados en rumiantes de algunas comunidades altoandinas, han permitido detectar anticuerpos contra los virus respiratorio sincitial (RS), parainfluenza 3 (PI3), diarrea viral bovina y otros agentes que afectan el tracto respiratorio y gastrointestinal, indicando que estos virus, componentes del complejo respiratorio, están presentes en la ganadería mixta altoandina
(Ameghino, 1990; Manchego et al., 1998; Alvarez et al., 2002; Victorio et al., 2004; Cabello et al., 2007). El sistema de manejo, desnutrición, elevada carga parasitaria y clima, entre otros, podrían contribuir a una disminución de las defensas innatas de los animales, especialmente de los jóvenes, predisponiéndolos a infecciones secundarias bacterianas o virales como los virus RS y PI, que usualmente circulan en la población de bovinos adultos (Victorio et al., 2004).

El presente trabajo tuvo por objetivo determinar anticuerpos contra los virus neumotrópicos RS y PI3 en bovinos de la provincia de Espinar, departamento del Cusco.

\section{Materiales y Métodos}

\section{Lugar de Estudio}

El estudio se realizó en la microcuenca de Ccañipía, provincia de Espinar, ubicada en la zona sureste del departamento del Cusco. El ganado, predominantemente de raza Brown Swiss y sus cruces con ganado crio11 , es criado en forma extensiva sobre pasturas naturales y cultivadas. La toma de muestras se realizó entre junio y julio de 2007. Durante los meses del muestreo se registró una temperatura media mensual de 4.1 y 3.6 ${ }^{\circ} \mathrm{C}$, precipitación total mensual de 0 y $3.4 \mathrm{~mm}$, y humedad relativa media mensual de 53.7 y $51.2 \%$, respectivamente (SENAMHI, 2008).

\section{Animales y Muestras}

El tamaño de muestra $(\mathrm{n}=282)$ fue obtenido mediante el método no paramétrico de muestreo simple al azar, considerando una 
prevalencia referencial de $68 \%$ (Victorio et al., 2004), con un nivel de confianza del $95 \%$ y un error de 5\% (Daniel, 1996). No obstante, el estudio se realizó con 406 bovinos de ambos sexos, mayores de 6 meses, pertenecientes a 114 criadores de tres comunidades (Huisa Collana, Anta Ccollana y Huarca).

Se colectó muestras de sangre de la vena yugular. Los sueros se separaron por centrifugación y se trasladaron al Laboratorio de Virología de la Facultad de Medicina Veterinaria (FMV) de la Universidad Nacional Mayor de San Marcos (UNMSM). La distribución de muestras por grupo etario (612, 13-24, >24 meses) se indica en el Cuadro 1.

\section{Detección de Anticuerpos}

En la detección de anticuerpos contra los virus RS y PI3 se utilizó la prueba de neutralización viral, utilizando como antígeno las cepas Mohanty del virus RS y la cepa SF del virus PI3 titulados previamente, empleando microplacas para cultivo celular de 96 hoyos, según la técnica descrita en el Manual de la OIE (1996). Se utilizaron cultivos celulares secundarios de cornete nasal de feto bovino, cultivados y mantenidos en el Laboratorio de Virología de la FMV-UNMSM.

El título de suero fue la dilución más alta capaz de neutralizar el 100DI ${ }_{50} \mathrm{CC} / 50$ ? 1 del virus, evidenciado por la ausencia de efecto citopático en las células indicadoras. Títulos de sueros iguales o mayores a 1:2 fueron considerados positivos a anticuerpos contra los virus descritos.

\section{Análisis de Datos}

Se utilizó la prueba de Chi cuadrado para determinar la existencia de asociación entre las variables grupo etario, comunidad y la seropositividad de los animales, usando un nivel de significancia del 0.05. Los datos se analizaron mediante el programa SPSS 9.

\section{Resultados y Discusión}

Los virus RS y PI3, conocidos también como virus respiratorios, tienen una distribución mundial en las poblaciones bovinas y humanas (Sullender, 2000; Henrickson, 2003). El $85.0 \pm 3.5$ y $87.4 \pm 3.2 \%$ de los bovinos presentaron anticuerpos contra los virus RS y PI3, respectivamente (Cuadro 1), evidenciando que ambos agentes virales están presentes en la población bovina de la zona. Los anticuerpos maternales o pasivos en el bovino se agotan en un promedio de 6 meses, y los criadores no utilizan la vacuna multivalente (RS, PI3, RIB, DVB), disponible en el país para la prevención de estas infecciones, de allí que los anticuerpos detectados contra estos virus fueron inducidos por virus de campo.

La principal actividad ganadera en Ccañipía es la crianza del ganado bovino criollo para la producción de leche a base de forraje natural o cultivado. Es una zona con potencial para el desarrollo de la ganadería lechera y los ganaderos tienen gran interés en mejorar e incrementar la población bovina a través de la compra de animales locales. Posiblemente, como consecuencia de la compra-venta de animales, se han incrementado los problemas respiratorios, sobre todo en terneros, así como los de tipo reproductivo, constituyendo un serio problema socio-económico para las familias altoandinas.

Los virus RS y PI3 no son los únicos agentes causantes de los problemas respiratorios en el bovino de esta región. Los virus de la diarrea viral bovina (VDVB) y rinotraqueitis infecciosa bovina (VRIB) han sido detectados serológicamente en esta misma población de bovinos, con prevalencias de 56.2 y $27.8 \%$, respectivamente (H. Rivera, Lima, comunicación personal). Asimismo, se han detectado anticuerpos contra estos virus en bovinos y otros rumiantes de 
Cuadro 1. Seroprevalencia de los virus Respiratorio Sincitial (RS) y Parainfluenza 3 (PI3) en bovinos de la zona de Ccañipía, Espinar, Cusco, según grupo etario (2007)

\begin{tabular}{cccccc}
\hline \multirow{2}{*}{$\begin{array}{c}\text { Edad } \\
(\text { meses })\end{array}$} & $\begin{array}{c}\text { Animales } \\
(\mathrm{n})\end{array}$ & \multicolumn{2}{c}{$\begin{array}{c}\text { Animales con anticuerpos } \\
\text { contra el RS }\end{array}$} & \multicolumn{2}{c}{$\begin{array}{c}\text { Animales con anticuerpos } \\
\text { contra el PI3 }\end{array}$} \\
\cline { 3 - 6 } & & $\mathrm{N}$ & $\% \pm \mathrm{IC}$ & $\mathrm{n}$ & $\% \pm \mathrm{IC}$ \\
\hline $6-12$ & 87 & 42 & $48.3 \pm 10.4$ & 43 & $49.4 \pm 9.5$ \\
$13-24$ & 85 & 85 & 100 & 83 & $97.6 \pm 3.6$ \\
$>24$ & 234 & 218 & $93.1 \pm 3.2$ & 229 & $97.7 \pm 2.1$ \\
\hline Total & 406 & 345 & $85.0 \pm 3.5$ & 355 & $87.4 \pm 3.2$ \\
\hline
\end{tabular}

Cuadro 2. Distribución porcentual de los títulos de anticuerpos contra el virus Respiratorio Sincitial (RS) y el virus Parainfluenza 3 (PI3) en suero de bovinos de la zona de Ccañipia, Espinar, Cusco (2007)

\begin{tabular}{ccccccccc}
\hline \multirow{2}{*}{$\begin{array}{c}\text { Grupo } \\
\text { etario }\end{array}$} & \multicolumn{3}{c}{$\begin{array}{c}\text { Inversa de los títulos de anticuerpos } \\
\text { contra el RS }\end{array}$} & \multicolumn{4}{c}{$\begin{array}{c}\text { Inversa de los títulos de anticuerpos } \\
\text { contra el PI3 }\end{array}$} \\
\cline { 2 - 9 } (meses) & $\mathrm{N}^{\circ}$ & $2-8$ & $16-64$ & $128->256$ & $\mathrm{~N}^{\circ}$ & $2-8$ & $16-64$ & $128->256$ \\
\hline $6-12$ & 42 & 40.5 & 57.1 & 2.4 & 43 & 27.9 & 62.8 & 9.3 \\
$13-24$ & 85 & 32.9 & 58.8 & 8.2 & 83 & 15.7 & 62.7 & 21.7 \\
$>24$ & 218 & 20.6 & 63.3 & 16.1 & 229 & 6.1 & 55.9 & 38.0 \\
\hline Total & 345 & 26.0 & 61.4 & 12.4 & 355 & 10.9 & 58.3 & 30.7 \\
\hline
\end{tabular}

Cuadro 3. Número y porcentaje de animales con anticuerpos contra el virus Respiratorio sincitial (RS) y el virus Parainfluenza 3 (PI3) en forma simultánea, según grupo etario (2007)

\begin{tabular}{cccc}
\hline \multirow{2}{*}{$\begin{array}{c}\text { Edad } \\
(\text { meses })\end{array}$} & $\begin{array}{c}\text { Animales } \\
(\mathrm{n})\end{array}$ & \multicolumn{2}{c}{$\begin{array}{c}\text { Animales con anticuerpos contra } \\
\text { los virus RS y PI3 }\end{array}$} \\
\cline { 3 - 4 } & & $\mathrm{N}^{\circ}$ & $\% \pm \mathrm{IC}^{1}$ \\
\hline $6-12$ & 87 & 29 & $33.3 \pm 9.8$ \\
$13-24$ & 85 & 64 & $75.3 \pm 9.2$ \\
$>24$ & 234 & 217 & $92.7 \pm 3.5$ \\
\hline Total & 406 & 310 & $76.4 \pm 4.2$ \\
\hline${ }^{1}$ Intervalo de confianza del 95\% & &
\end{tabular}

varias comunidades del Cusco, Puno y Arequipa (Manchego et al., 1998; Alvarez et al., 2002; Victorio et al., 2004; Cabello et al.,
2006). Además, antígenos de los virus RS y PI3, así como Pasteurella multocida, Mannheimia hemolitica e infecciones mix- 
tas entre virus y bacterias han sido detectados en pulmones de casos fatales de alpacas de varias zonas del Cusco y Puno (Cirilo, 2008), de modo que es posible que otros agentes virales aún no investigados, como los adenovirus y coronavirus respiratorio también estén presentes.

La alta prevalencia de los virus RS y PI3 es similar a la reportada en bovinos de un rebaño mixto de la comunidad de Chahuaytiri, Cusco (Cabello et al., 2006) y en alpacas del Cusco (Victorio et al., 2004), sugiriendo que estos virus tienen una amplia distribución en poblaciones mixtas de ganado. Los virus DVB, RIB, RS y PI3 son agentes inmunosupresores y podrían permanecer en la población de rebaños mixtos favorecidos por el clima, presencia de otras infecciones, desnutrición, y alta carga parasitaria, entre otros, y posiblemente, son los agentes primarios de la ocurrencia de neumonías en los terneros menores a 6 meses.

Todos los ganaderos presentaron animales positivos indicando la gran dispersión de estos virus en la zona. La prevalencia de ambos virus fue mayor en el grupo etario de 13 a >24 meses de edad (Cuadro 1), posiblemente debido a la presencia de algún factor de estrés en estos animales que favorece reinfecciones con o sin signos respiratorios. En adultos, sobre todo el PI3, es de tipo subclínico a menos que sea parte de infecciones concomitantes con otros virus y bacterias como $P$. multocida, M. haemolitica, micoplasma, etc. y factores de estrés que en conjunto inmunodeprimen al animal (van der Poel et al., 1994; Sullender, 2000).

El virus RS produce una inmunidad incompleta de modo que no protege contra reinfecciones (van der Poel et al., 1993). Es así que los terneros pueden reinfectarse tres semanas después de haber tenido una infección primaria con el virus (Stott y Taylor, 1984). En humanos, esta pobre respuesta inmunitaria contra el virus RS está siendo asociada con persistencia viral, aunque no se ha detectado las células que contenga el RNA o RNAm del virus RS; sin embargo, se estima que el virus puede persistir en el pulmón donde podría replicarse manteniendo la infección y el RNA sin ser degradado por las ribonucleasas (Schwarze et al., 2004).

Los títulos de anticuerpos contra los virus RS y PI3 estuvieron en un rango de 2 a $>256$, confirmando el concepto de frecuentes desafíos de los animales por ambos virus. La mayoría de los animales tuvieron títulos de 16 a 64 contra ambos virus, seguido por los títulos de 128 a >256 en el caso del virus IP3 (Cuadro 2). Los títulos de anticuerpos mayores a 16, hallados en animales adultos, sugieren que son producto de frecuentes reinfecciones, y posiblemente, por factores de estrés climático, alimenticio y de preñez.

La alta prevalencia y los títulos de anticuerpos detectados indican que existen factores que promueven la transmisión viral. Entre estos podrían considerarse, además del clima, el transporte de los animales a las ferias que son realizadas con frecuencia y donde se realiza la compra-venta de animales con fines de crianza. Los resultados también evidencian infecciones concomitantes, ya que el $76.4 \%$ de los animales presentó anticuerpos contra ambos virus (Cuadro 3). Estas infecciones mixtas podrían conllevar a la ocurrencia del complejo respiratorio y muerte del animal (Speer et al., 2001).

El nivel de seropositividad de animales de 6 a 12 meses fue diferente $(p<0.05)$ de los grupos etarios 6-12 y >24, dado que los animales de mayor edad tienen más riesgo de sufrir reinfecciones y responder con anticuerpos que los animales de menor edad. Esto es indicativo que el virus se encuentra circulando en los animales en estudio. Los resultados permiten concluir que los virus Respiratorio Sincitial y Parainfluenza 3 están presentes en bovinos de crianza semi-extensiva de la zona de Ccañipía, provincia de Espinar, Cusco, con prevalencias de $85.0 \pm 3.5$ y $87.4 \pm 3.2 \%$, respectivamente. 


\section{Agradecimientos}

El trabajo fue financiado por el Consejo Superior de Investigaciones de la UNMSM. Los autores agradecen al Dr. Mario García por la revisión crítica del manuscrito.

\section{Literatura Citada}

1. Alagón G. 2007. Plan de evaluación y monitoreo de los sistemas de producción ganaderos de la Microcuenca de CcañipíaEspinar. Cusco: FREDERMICE. 48 p.

2. Alvarez S, Rivera H, Pezo D, García W. 2002. Detección de anticuerpos contra pestivirus en rumiantes de una comunidad campesina de la provincia de Canchis, Cusco. Rev Inv Vet, Perú 13(1): 46-51.

3. Ameghino E. 1990. Neumonías. Avances sobre investigación en salud animal camélidos sudamericanos. Bol Div IVITA-UNMSM 23: 25-31.

4. Cabello K, Quispe R, Rivera H. 2006. Frecuencia de los virus Parainfluenza-3, Respiratorio Sincitial y Diarrea Viral Bovina en un rebaño mixto de una comunidad campesina de Cusco. Rev Inv Vet, Peru 17: 167-172.

5. Cirilo E. 2008. Identificación de agentes virales y bacterianos causantes de neumonías agudas en crías de alpacas. Tesis de Magíster. Lima: Universidad Nacional Mayor de San Marcos. 93 p.

6. Daniel W. 1996. Bioestadísticas: base para el análisis de las ciencias de salud. $3^{\mathrm{a}}$ ed. México DF: Limusa. 352 p.

7. Henrickson KJ. 2003. Parainfluenza virus. Clin Microbiol Rev 16: 242-264.

8. Manchego A, Rivera H, Rosadio $R$. 1998. Seroprevalencia de agentes virales en rebaño mixto de una comunidad andina peruana. Rev Inv Pec IVITA 9(2): 1-10.

9. [MINAG] Ministerio de Agricultura, Perú. 1996. Producción pecuaria e industria avícola. Lima: Presidencia de la República, MINAG. 14 p.

10. [OIE] Office International des Epizooties. 1996. Bovine Viral Diarrhoea. In: Manual of standards diagnostic tests and vaccines. Paris: OIE. p 651-658.

11. Schwarze J, O'Donnell D, Rohwedder A, Openshaw P. 2004. Latency and persistence of respiratory Syncytial Virus despite T cell immunity. Am J Resp Crit Care 169: 801-805.

12. [SENAMHI] Servicio Nacional de Meteorología e Hidrología. 2008. Oficina de Estadística e Informática. Estación metereológica de Yauri, Espinar. Cusco: SEANHMI. 4 p.

13. Speer NC, Young C, Roeber D. 2001. The importance of preventing bovine respiratory disease: a beef industry review. Bovine Practitioner 35: 189-196.

14. Sullender WM. 2000. Respiratory syncytial virus genetic and antigenic diversity. Clin Microbiol Rev 13: 1-15.

15. van der Poel, Kramps J, Middel W, Van Oirshot J, Brand A. 1993. Diagnosis of bovine respiratory sycytial virus infections: a longitudinal epidemiological study in dairy herds. Arch Virol 133: 309-321.

16. van der Poel, Brand A, Kramps A, Van Oirschot J. 1994. Respiratory syncytial virus infection in human beings and in catle. J Infect Dis 29: 215-228.

17. Victorio W, Rosadio R, Rivera H, Manchego A. 2004. Seroprevalencia de virus neumopatógenos en alpacas adultas de la provincia de Canchis, Cusco. Rev Inv Vet, Perú 15: 127-131. 